\title{
The Three Scales of Submarine Groundwater Flow and Discharge across Passive Continental Margins
}

\author{
John F. Bratton \\ U.S. Geological Survey, Woods Hole Coastal and Marine Science Center, 384 Woods Hole \\ Road, Woods Hole, Massachusetts 02543-1598, U.S.A. \\ (e-mail: jbratton@usgs.gov)
}

\begin{abstract}
A B S T R A C T
Increased study of submarine groundwater systems in recent years has provided a wealth of new data and techniques, but some ambiguity has been introduced by insufficient distinguishing of the relevant spatial scales of the phenomena studied. Submarine groundwater flow and discharge on passive continental margins can be most productively studied and discussed by distinct consideration of the following three spatial scales: (1) the nearshore scale, spanning approximately $0-10 \mathrm{~m}$ offshore and including the unconfined surficial aquifer; (2) the embayment scale, spanning approximately $10 \mathrm{~m}$ to as much as $10 \mathrm{~km}$ offshore and including the first confined submarine aquifer and its terminus; and (3) the shelf scale, spanning the width and thickness of the aquifers of the entire continental shelf, from the base of the first confined aquifer downward to the basement, and including influences of geothermal convection and glacioeustatic change in sea level.
\end{abstract}

\section{Introduction}

Following the publication of several important papers in the 1990s, especially those by Moore (1996, 1999), and the formation of the Scientific Committee on Ocean Research (SCOR) working group on submarine groundwater discharge (SGD) in 1997 (Burnett 1999), the study of submarine groundwater discharge and related phenomena expanded rapidly. Among the issues that have motivated the development of a better understanding of this topic are balancing of ocean elemental budgets (Shaw et al. 1998; Charette et al. 2005), remediating eutrophication and other types of contamination of coastal water bodies (Giblin and Gaines 1990; Portnoy et al. 1998), protecting coastal groundwater supplies from saltwater intrusion (Barlow 2003), and ensuring the health of groundwater-dependent coastal ecosystems (Valiela et al. 1990). Given rapid growth in this field, however, hydrogeologic processes that may be similar in terms of physics but that operate at different spatial scales have not always been adequately distinguished from each other.

Burnett et al. (2003) defined SGD as "any and all 2010 .

Manuscript received September 24, 2009; accepted May 19,

[The Journal of Geology, 2010, volume 118, p. 565-575] No copyright is claimed for this article. It remains in the public domain. DOI: $10.1086 / 655114$ flow of water on continental margins from the seabed to the coastal ocean, regardless of fluid composition or driving force" (p. 6), and Moore (2010) modified this to "the flow of water through continental margins from the seabed to the coastal ocean, with scale lengths of meters to kilometers" (p. 71; emphasis added) to exclude shear flow and flow driven by benthic fauna. While these definitions have clarified the full scope of what some of the leaders in the field consider to fall under this umbrella term, the nomenclature of the component parts is still unstable. Various terms, acronyms, and units have been proposed to differentiate and quantify distinct parts of the submarine aquifer and discharge system. These include submarine fresh groundwater discharge (SFGD), recirculated saline groundwater discharge (RSGD), and submarine groundwater recharge (SGR; Taniguchi et al. 2002); deep pore water upwelling (DPU; Moore 2010); the shallow and deep salinity transition zones (STZs; Kroeger and Charette 2008); the freshwater-saltwater interface (FSI; various authors); and discharge units of volume per unit time, volume per unit time per unit length of shoreline, and volume per unit time per unit area of seafloor (Taniguchi et al. 2002). 
Consensus on how to properly describe or discuss some SGD-related concepts and on the appropriate use of terms, acronyms, and discharge units does not yet exist in the field. This can create confusion and can make comparison of results from related studies difficult. Some of this confusion and lack of consensus is likely the result of rapidly evolving understanding of SGD-related phenomena due to new data and simultaneous development of new measurement techniques and changing interpretations of previous measurements.

More explicit consideration of different spatial scales in submarine groundwater investigations rather than a strictly process-based focus may improve clarity and understanding. This would facilitate incorporation of important aspects of hydrogeology (Kazemi 2008; McCoy and Corbett 2009), including submarine flow paths and travel time, as well as distinct ecological aspects of the interaction of submarine groundwater with surface water (hydroecology) that are not driven exclusively by organisms themselves. Such conceptualization would likely impact both motivations for and methods of study. Here I will attempt to clarify the most appropriate subdivisions of scale in submarine groundwater studies, with the ultimate aim of fostering clarity in both the formulation of SGDrelated research plans and the presentation of results such that separate processes and phenomena are not conflated. The scope of the discussion will be intentionally limited, ignoring the vast areas of saline groundwater or sediment pore water with very limited flow that are believed to exist under much of the open ocean, as well as the hydrothermal systems of vigorous groundwater circulation that occur at plate boundaries, and paying particular attention to the U.S. Atlantic margin as a representative illustration. The widths and thicknesses of the zones of flow and discharge in the included schematic figures are shown for reference only and would vary significantly on the basis of local conditions.

At steady state, the water table elevation and position of the fresh-saline interface in a homogeneous coastal aquifer can be determined reasonably well by a Dupuit-Ghyben-Herzberg analysis that is modified to incorporate an outflow face (Vacher 1988). Such analyses, however, are inadequate to describe many of the temporal and spatial complexities of natural and perturbed coastal and submarine aquifer systems investigated in recent years. For example, many important aspects of shallow coastal aquifers and their interactions with the coastal ocean are transient and cannot be usefully approximated by steady-state assumptions. These phenomena would include influences of sea-level fluctuations due to tides, waves, and storms (Robinson et al. 2006, 2007; Li et al. 2008). They would also include water table fluctuations due to seasonal variations in recharge and evapotranspiration as well as during recharge pulses caused by heavy rainfall (Smith et al. 2008) or rapid snow melt, or disturbance by sustained onshore pumping (McAuley et al. 2001; Foyle et al. 2002).

Simulation also becomes more complicated where the common situation of confined or semiconfined offshore flow occurs (Bratton et al. 2004, 2009; Bratton 2007; Li et al. 2007). Field studies and related variable-density flow models are now showing that the typical configuration along mesotidal coasts is best described by multiple, stacked, saline to brackish recirculation cells and discharge of fresh to brackish water in multiple shore-parallel bands, alternating shore-perpendicular zones of low discharge and high discharge, or discrete submarine springs. While numerical techniques exist to address all of these situations, appropriate offshore data are generally rare, and this conceptual framework is not yet widely appreciated by many coastal scientists and managers. To help remedy this, a reasonable way to organize consideration of submarine groundwater flow and discharge phenomena on passive continental margins is presented here. It consists of separation of margin hydrogeology into three spatial scales: (1) the nearshore scale, (2) the embayment scale, and (3) the shelf scale.

\section{Nearshore Scale}

For several reasons, the nearshore zone (fig. 1), located within approximately $10 \mathrm{~m}$ of shore, extending down to the first confining unit, and including the intertidal zone, has received the most research attention in recent years. This is likely due to its accessibility, the presence of observable discharge at low tidal stages, and its direct association with the unconfined surficial aquifer and topographically driven flow (Wilson 2005). Nearshore groundwater discharge can also have significant direct impact on shallow coastal ecosystems. Studies that began with manual subtidal seepage meters eventually expanded to incorporate the use of tools such as intertidal seepage meters, automated seepage and salinity meters, offshore piezometers and wells, piezomanometers, thermistors and fiberoptic distributed temperature sensing cables, water quality and radioisotope time series instruments, aerial infrared imaging, and stationary electrical resistivity arrays. The numerous studies that have been conducted to document groundwater dynam- 


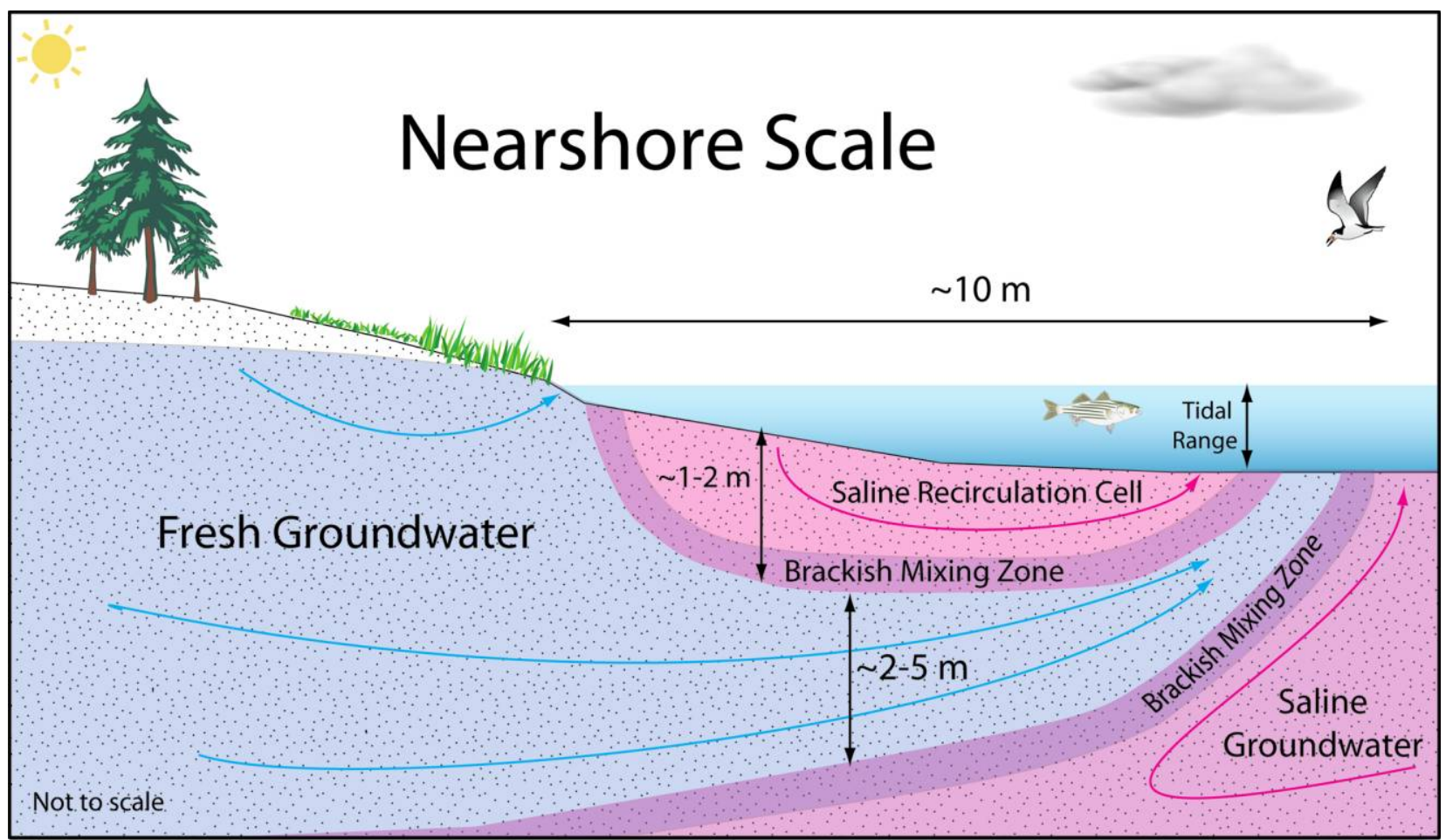

Figure 1. Schematic diagram of the nearshore scale of submarine groundwater flow and discharge showing the intertidal recirculation cell and the zone of discharge of reduced-salinity water beyond the low-tide line. The widths and thicknesses of the zones of flow and discharge shown could vary significantly on the basis of local conditions.

ics at this scale (e.g., Burnett et al. 2006) came to dominate publications on the topic; by comparison, other scales were relatively understudied during this time.

One important finding of studies of nearshorescale phenomena, which has only recently been well documented and modeled (Michael et al. 2005; Robinson et al. 2006, 2007; Li et al. 2008), was that nearshore systems with significant tides tend to form shallow saline recirculation cells. These cells are flushed with saline seawater over periods of hours to days and tend to result in a displacement toward deeper water of the lower part of the fresh seepage face by several meters.

A recent development that was particularly relevant to nearshore SGD studies was more widespread appreciation of the fact that elevated activities of short-lived radium isotopes in surface water were not primarily derived from fresh discharge but rather from recirculated brackish to saline discharge (Moore 1996; Mulligan and Charette 2006). This meant that radium-derived values interpreted by some as quantifying fresh discharge were often too high, sometimes by an order of magnitude or more. It also meant that radium sources other than groundwater, such as fluvial inputs to estuaries and water from the open shelf advected into shallower water, as well as local temporal and spatial variations in the radium activities of discharging groundwater itself, needed to be taken more explicitly into account in the development of radiumderived budgets of groundwater discharge. Uncertainties in the application of radium isotopes in SGD studies are decreasing, and recent studies continue to provide novel and significant results, especially at larger scales (e.g., Moore et al. 2008).

Radon has also been used as a radiogenic tracer of submarine groundwater discharge in nearshore settings. Radon-222, which has a short half-life of $3.8 \mathrm{~d}$, is often concentrated in fresh groundwater relative to both shallow saline groundwater and marine surface water, so it can be measured in surface water and used to calculate the amount of lowsalinity groundwater that has recently discharged to an estuary or bay (Cable et al. 1996; Burnett et al. 2001; Crusius et al. 2005). Care must be taken, however, to properly constrain the radon activity of the groundwater end-member in order to use this method (Mulligan and Charette 2006; Burnett et al. 2007). 


\section{Embayment Scale}

At the next level above the nearshore scale is the embayment or inner continental shelf scale (fig. 2), operationally defined as extending $10 \mathrm{~m}$ to $10 \mathrm{~km}$ offshore and to depths of about $5-50 \mathrm{~m}$ below the seafloor, including the first confined or semiconfined portion of a submarine flow system. A strict definition of the outer edge of this zone is not possible because it is not directly controlled by oceanographic phenomena such as wave base or seafloor morphology. Rather, it extends to the outer edge of the shallowest submarine-confined aquifer, including its discharge zone. The shallowest submarine confining unit (Bratton 2007) permits primarily topographically driven regional flow of fresh or brackish water offshore beneath the nearshore zone and sometimes entirely beneath lagoons, shallow estuaries, embayments, and barrier islands (Bratton et al. 2009). The origin of the shallowest confining unit can vary, but it is commonly a fine-grained deposit laid down during the sea-level highstands of the last interglacial interval, especially Marine Isotope Stage $5 \mathrm{e}$, or a more recent trangressional unit consisting of estuarine and tidal flat muds, as well as peat from drowned salt marshes or mangroves. At high latitudes, submerged permafrost may also play a significant role in submarine aquifer systems at these scales (Harrar et al. 2001; Rachold et al. 2007). When compared with the nearshore zone, relatively little is known about the dynamics of submarine groundwater systems at this scale. Striking examples terminate in offshore springs, particularly in carbonate settings (Colbourne and Hay 1990; Swarzenski et al. 2001; Fleury et al. 2007).

Some embayment-scale flow systems that terminate abruptly at offshore paleochannels or other erosional truncations or depositional terminations in the shallow subsurface have been documented by continuous resistivity profiling and barge-based or jack-up rig drilling (Foyle et al. 2002; Manheim et al. 2004; Bratton et al. 2009). The exact nature of discharge in most of these cases (e.g., diffuse vs. focused in lines of springs) is not well documented, but the volumes of water involved are potentially substantial. The discharging water can favorably alter salinity, water chemistry, and temperature for certain organisms. Because of the longer flow paths

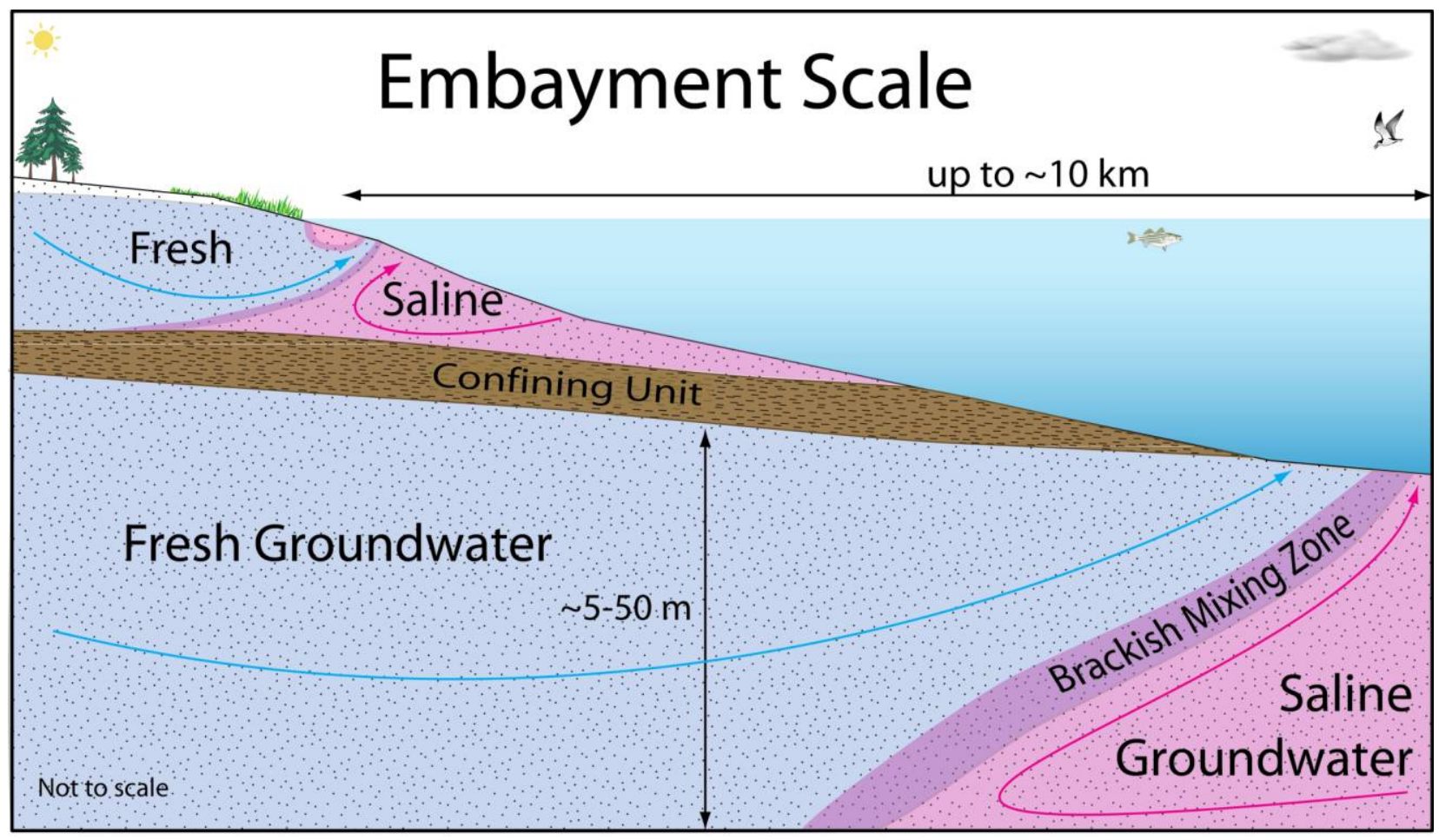

Figure 2. Schematic diagram of the embayment or inner-shelf scale of submarine groundwater flow and discharge showing submarine flow of low-salinity water in the first confined aquifer and the zone of offshore discharge beyond the edge of the submarine confining unit. 


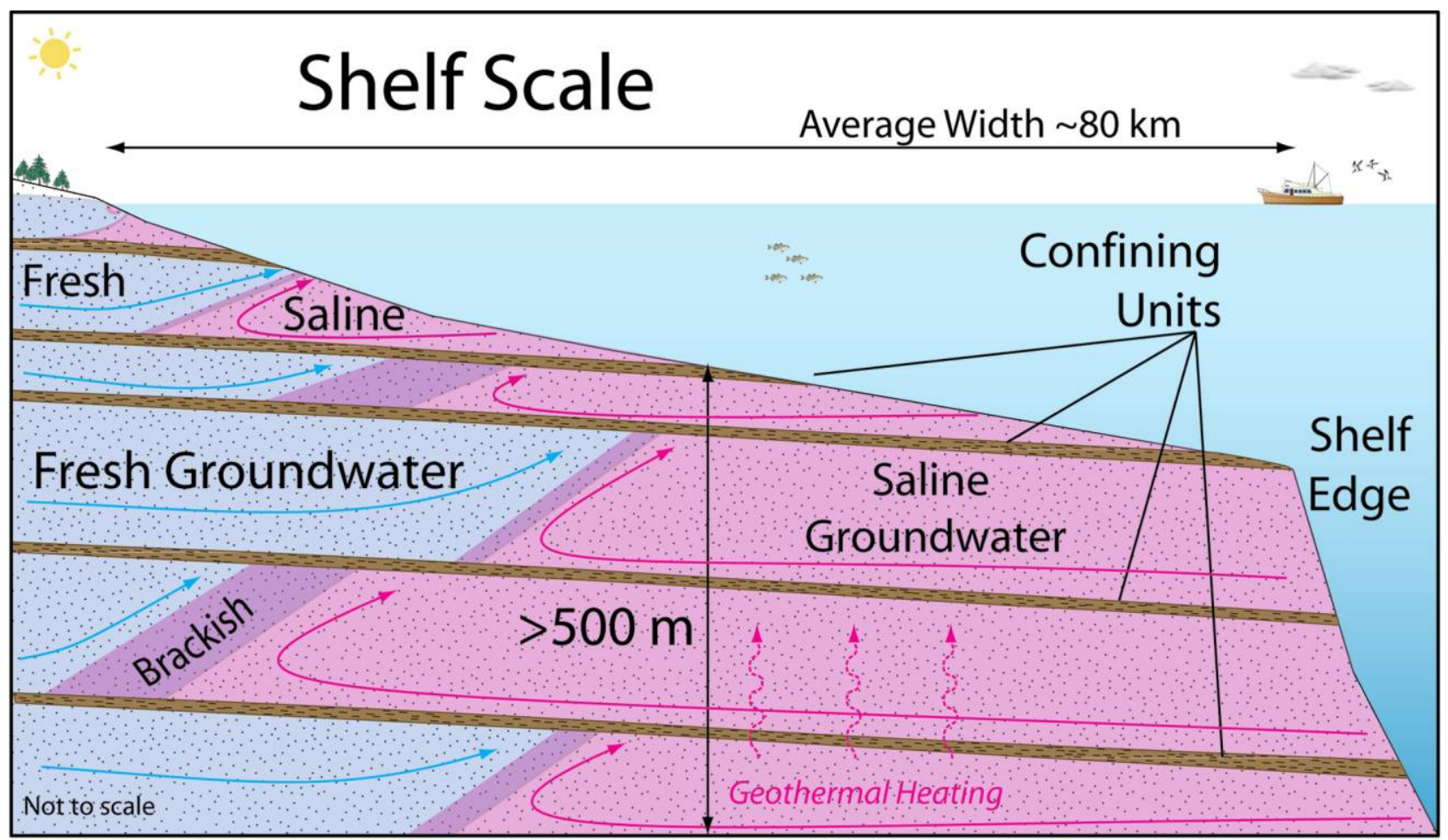

Figure 3. Schematic diagram of the continental-shelf scale of submarine groundwater phenomena showing the variable position of the fresh-saline interface in multiple confined aquifers on the shelf, the variable widths of the mixed zone at the interface, the flow of saline water inward from the exposed edges of confined aquifers, and the upward movement of saline groundwater induced by geothermal heating at depth.

that carry groundwater recharged on land into these offshore discharge zones, the water currently being discharged is often too old to have been impacted by common anthropogenic pollutants such as nitrate (Portnoy et al. 1998; Kroeger and Charette 2008), pesticides, solvents, or hydrocarbons. This is not the case for nearshore discharge.

Because of the relative purity of some of this old, offshore water, inner-shelf aquifers such as these have been examined as potential sources of drinking water for coastal communities in many locations (Edmunds 2001). Current or imminent eutrophication from discharge of nutrients associated with these waters is generally not an issue, and it will not be for decades to centuries except where intentional injection of nutrients into these systems has been performed on a large scale (e.g., Paul et al. 1997; Hunt 2007; Maliva et al. 2007). Applying radioisotopic approaches to quantifying discharge at this scale, as was described above for the nearshore scale, is more complicated because of the greater dilution and generally more diffuse nature of SGD in open embayments or inner-shelf waters.

\section{Shelf Scale}

The next-larger scale is that of the entire continental shelf (fig. 3), which may include multiple confined aquifer systems extending below the first confined aquifer to depths of $500 \mathrm{~m}$ or more below the seafloor and to the outer continental shelf edges, submarine canyon incisions, and even the continental slope, especially during sea-level lowstands. The primary process driving flow at this scale is usually geothermal convection, which produces seawater recirculation through the shelf (Kohout 1967; Wilson 2005; Hughes et al. 2007, 2009). Sediment compaction and associated dewatering, as well as brine-related processes, are also important in some settings (Wilson and Ruppel 2007). It could be argued that there is actually more known about the occurrence of submarine groundwater systems at the shelf scale, including relict reduced-salinity groundwater, than is known about intermediate embayment-scale submarine aquifer systems in some settings. This is mostly a result of ancillary data collected as part of offshore oil exploration as well as scientific drilling through the 
Table 1. Summary Characteristics of Each Scale of Submarine Groundwater Flow and Discharge

\begin{tabular}{|c|c|c|c|}
\hline & Nearshore scale & Embayment scale & Shelf scale \\
\hline Typical width & $10 \mathrm{~m}$ & Up to $10 \mathrm{~km}$ & $80 \mathrm{~km}$ \\
\hline Typical thickness & $2-5 \mathrm{~m}$ & $5-50 \mathrm{~m}$ & $>500 \mathrm{~m}$ \\
\hline Dominant processes & $\begin{array}{l}\text { Topographically } \\
\text { driven flow, inter- } \\
\text { tidal and subtidal } \\
\text { saline recirculation }\end{array}$ & $\begin{array}{l}\text { Topographically } \\
\text { driven flow, subtidal } \\
\text { saline recirculation }\end{array}$ & $\begin{array}{l}\text { Geothermal convec- } \\
\text { tion, also compac- } \\
\text { tion dewatering }\end{array}$ \\
\hline Recharge & $\begin{array}{l}\text { Surficial terrestrial, } \\
\text { intertidal saline, and } \\
\text { shallow subtidal } \\
\text { saline }\end{array}$ & $\begin{array}{l}\text { Surficial and confined } \\
\text { terrestrial, subtidal } \\
\text { saline }\end{array}$ & $\begin{array}{l}\text { Confined terrestrial, } \\
\text { subtidal and shelf- } \\
\text { edge saline }\end{array}$ \\
\hline Discharge & $\begin{array}{l}\text { Fresh and saline/ } \\
\text { brackish, intertidal } \\
\text { and shallow subtidal }\end{array}$ & $\begin{array}{l}\text { Fresh and saline/ } \\
\text { brackish, subtidal }\end{array}$ & $\begin{array}{l}\text { Saline/brackish, sub- } \\
\text { tidal and shelf edge }\end{array}$ \\
\hline Upper bound & $\begin{array}{l}\text { Intertidal surface and } \\
\text { seafloor }\end{array}$ & $\begin{array}{l}\text { Top of uppermost con- } \\
\text { fining unit and in- } \\
\text { ner shelf seafloor }\end{array}$ & $\begin{array}{l}\text { Base of uppermost } \\
\text { confined aquifer, } \\
\text { outer shelf/slope } \\
\text { seafloor }\end{array}$ \\
\hline Lower bound & $\begin{array}{l}\text { Top of uppermost con- } \\
\text { fining unit }\end{array}$ & $\begin{array}{l}\text { Top of first confining } \\
\text { unit below } \\
\text { uppermost }\end{array}$ & Basement \\
\hline Inner bound & $\begin{array}{c}\text { Downward projection } \\
\text { of high tide line }\end{array}$ & $\begin{array}{l}\text { Downward projection } \\
\text { of high tide line }\end{array}$ & $\begin{array}{l}\text { Downward projec- } \\
\text { tion of high tide } \\
\text { line }\end{array}$ \\
\hline Outer bound & $\begin{array}{l}\text { Intersection of upper- } \\
\text { most confining unit } \\
\text { with seafloor }\end{array}$ & $\begin{array}{l}\text { Intersection of confin- } \\
\text { ing unit at base } \\
\text { with seafloor }\end{array}$ & $\begin{array}{l}\text { Downward projec- } \\
\text { tion of toe of con- } \\
\text { tinental slope }\end{array}$ \\
\hline
\end{tabular}

Deep Sea Drilling Program (DSDP), the Ocean Drilling Program (ODP), and the Integrated Ocean Drilling Program (IODP).

Classic work on the U.S. Atlantic shelf included studies of the Florida platform (Kohout 1966, 1967; Paull et al. 1991) as well as drilling of the Atlantic Margin Coring (AMCOR) Project and Continental Offshore Stratigraphic Test (COST) Program wells in the 1970s (Hathaway et al. 1979; Kohout 1988) and installation of submarine monitoring wells off New Jersey in 1985 (McAuley et al. 2001). Shelfscale groundwater processes, including both development of pore fluid overpressure due to sediment compaction and submarine spring sapping, were long hypothesized to impact the geomorphology of the shelf edge, including initiating slope failures and contributing to submarine canyon formation (Johnson 1939; Robb 1984; Orange et al. 1994). Some of these phenomena and processes are now being explored more quantitatively (Dugan and Flemings 2000, 2002; Green et al. 2007; Flemings et al. 2008). Other recent work has attempted to explain anomalously fresh groundwater beneath the shelves of the North Atlantic (Edmunds 2001; Person et al. 2003) and the relative roles of terrestrial recharge, marine recharge, and geothermal convection in shelf-scale groundwater circulation (Wilson 2003, 2005). Proposals to sequester carbon dioxide in saline aquifers beneath continental shelves have recently generated renewed interest in the occurrence of submarine groundwater at this scale (Chadwick et al. 2004).

\section{Integration of Scales}

Although the aim here is to improve clarity by distinguishing separate scales (table 1), compartmentalized understanding is not the ultimate objective. Integrating across two or even three scales is necessary to address particular issues of scientific and societal importance, such as how best to extract fresh groundwater or petroleum from coastal and submarine areas with minimal negative consequences, or how to mitigate impacts of sea-level rise on coastal ecosystems that live at or near the submarine groundwater halocline. With this in mind, the boundaries between scales and at the upper, lower, and outer edges of the entire SGD system become especially important.

The interface between the SGD system at the nearshore and embayment scales is the uppermost confining unit. The origin, depth, composition, thickness, and lateral continuity of this unit controls vertical flow into and out of the aquifers above and below it. Similarly, the contact between embayment and shelf scales is the confining unit at the base of the uppermost confined submarine aquifer. The stacked arrangement of these com- 


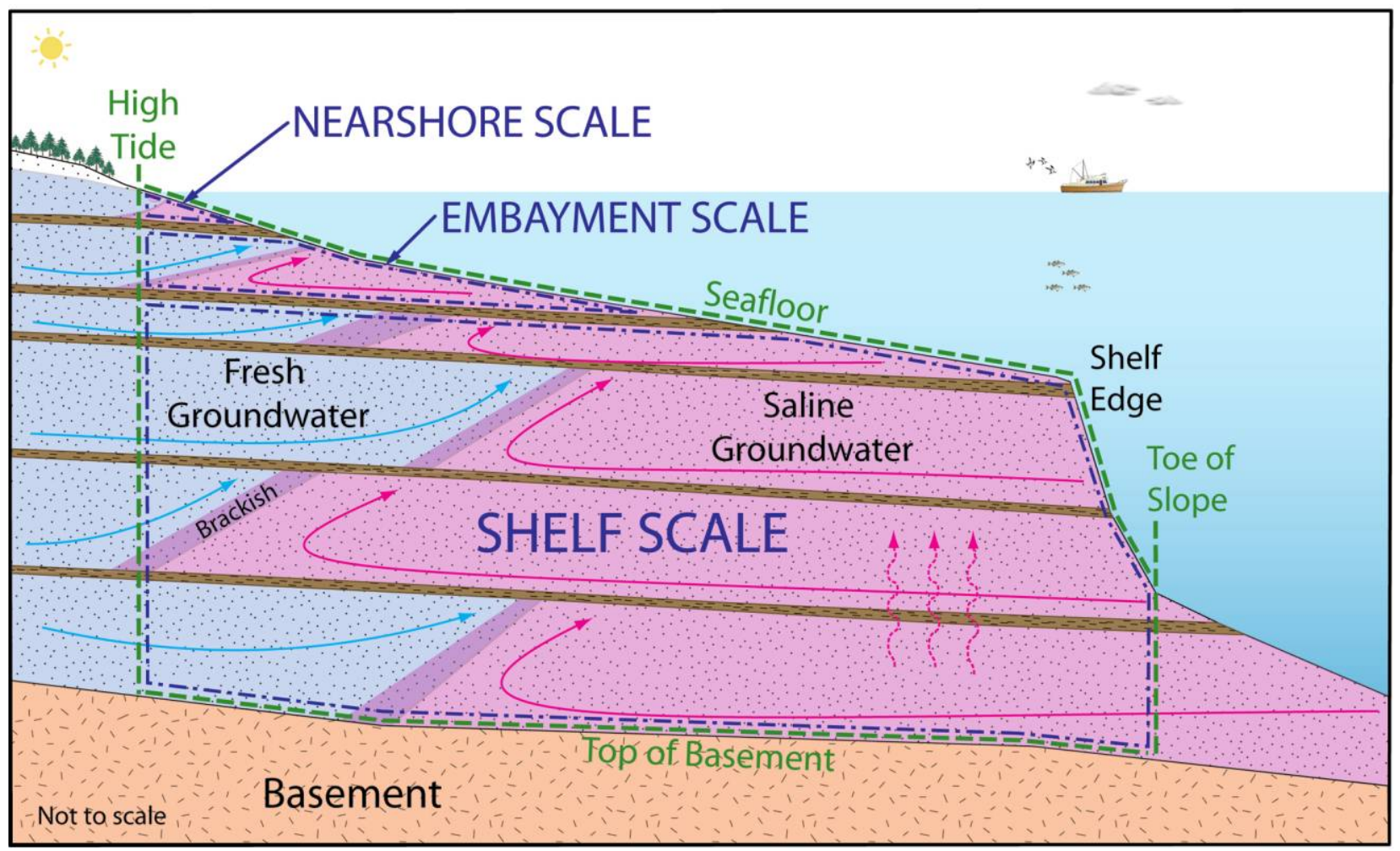

Figure 4. Summary diagram showing the three proposed spatial scales and the boundaries around the entire submarine groundwater flow and discharge system.

partments means that most SGD processes that span multiple scales are discontinuous or segmented, rather than forming a continuum. It also means that the system is dominated by anisotropy, with horizontal flow rates often exceeding vertical flow rates by an order of magnitude or more. Control of interaction between scale compartments by confining units highlights the significance of natural or engineered incision through such units or offsetting as the means by which cross-scale interaction can be greatly enhanced, at least locally. Relatively shallow incision can short-circuit barriers between the nearshore and embayment compartments. Deeper incision by submarine canyons and slides, penetration from below by diapirs, or offsetting by faults can connect flow systems of the embayment and shelf scales.

Finally, it is also important to understand the boundaries and interfaces surrounding the entire SGD system, including the atmosphere and intertidal vadose zone (at low tide); terrestrial aquifers; estuarine, coastal, and shelf surface water, as well as deep water beyond the shelf edge; and the hot brines, weathered and fractured basement aquifers, and, eventually, supercritical groundwater that ex- ists at depth. Practical surrounding boundaries on a passive margin could be considered to be (1) the vertical curtain underlying the high tide line (mean higher high water) at the shore, (2) the intertidal land surface and the seafloor below low tide and extending across the shelf and down the slope, (3) the vertical curtain underlying the toe of the continental slope, and (4) the basement surface (fig. 4).

\section{Ecological Significance}

Many recent studies have linked submarine groundwater discharge to the occurrence and health of important coastal ecosystems and fauna including, at the nearshore scale, salt marshes (Valiela et al. 1978; Krest et al. 2000; Charette 2007), mangroves (McGowan and Martin 2007), polychaetes (Dale and Miller 2008), bivalves (Taniguchi et al. 2008), and microbial pathogen assemblages (Boehm et al. 2004); and, at the embayment and shelf scales, coral reefs (Gagan et al. 2002; Paytan et al. 2006; Street et al. 2008), and fish (Culter 2006). The locations and chemistry of discharging water can have important impacts on benthic coastal ecosystems (Johannes 1980), particularly at the near- 
shore scale, even to the point of controlling their formation, their evolution, and the behavior of organisms living within them. Groundwater discharge maintains the salinity gradient in many estuaries that lack significant fluvial inputs, or where river flow is highly seasonal or episodic. At the embayment or shelf scales, especially in carbonate settings such as Florida (Swarzenski et al. 2001) or Australia's Great Barrier Reef (Stieglitz 2005), offshore springs frequented by a variety of fish species and sea turtles (Culter 2006) have been documented up to $50 \mathrm{~km}$ or more offshore. At the shelf scale, formation of submarine canyons, which commonly support diverse and abundant assemblages of marine organisms (e.g., Valentine et al. 1980), has been linked to groundwater processes described previously. Cold seeps in deep water are also associated with microbial mat formation and aggregations of chemosynthetic organisms such as bivalves and tube worms (Paull et al. 1984; Levin 2005).

\section{Implications for Ancient Processes}

Variation in sea level over geologic time scales has significantly modified the positions of shorelines and submarine groundwater discharge zones, shifting the three scale zones described above horizontally as well as alternately compressing and expanding the widths of the embayment and shelf zones. Highstands of sea level vertically and laterally drive seawater into continental margin aquifers, although establishment of aquifer density equilibrium usually lags behind transgression by centuries to millennia (Meisler et al. 1984) except in carbonate aquifers with high hydraulic conductivity. Land-based pumping can also affect the equilibrium position of the fresh-saline boundary in confined shelf aquifers (e.g., McAuley et al. 2001). Much of the residual impact of lowstand recharge is likely to manifest itself at the embayment scale. Adkins et al. (2002) estimated that lower sea level during the last glacial maximum allowed $4.5 \times 10^{6}$ $\mathrm{km}^{3}$ of freshwater to move into continental shelf aquifers, a volume approximately $75 \%$ larger than the estimated volume of water stored in modern glacial ice in Greenland. This volume of freshwater has generally not been accounted for in ice-age water budgets and paleoceanographic investigations.

\section{Conclusions}

Three scales of submarine groundwater flow and discharge are proposed: the nearshore scale, the embayment scale, and the shelf scale. The purpose of distinguishing these scales from each other is to improve the clarity of the design and reporting of results of field and modeling studies of groundwater flow and discharge phenomena on passive continental margins by providing a conceptual spatial framework for natural subdivision of the margins. Numerous research questions remain that are relevant to the different scales discussed, as well as the task of developing such a scheme for active margins. Logical alternatives to the proposal described here are encouraged, with the ultimate goal of developing consensus within the community of scientists that study submarine groundwater in such settings.

\section{A C K N O W LE D G M E N T S}

Ward Sanford, Holly Michael, Alicia Wilson, and two anonymous reviewers provided useful feedback and comments on drafts of this manuscript, which significantly improved it. The U.S. Geological Survey's Coastal and Marine Geology Program provided primary support for preparation of the manuscript and for participation in several field studies and scientific meetings that led to the recognition of the need for such a discussion. Some symbols used in the figures were courtesy of the Integration and Application Network (http://ian .umces.edu/symbols/l, University of Maryland Center for Environmental Science.

\section{R E F E R E N C E S C I T E D}

Adkins, J. F.; McIntyre, K.; and Schrag, D. P. 2002. The salinity, temperature and $\delta^{18} \mathrm{O}$ content of the glacial deep ocean. Science 298:1769-1773.

Barlow, P. M. 2003. Ground water in freshwater-saltwater environments of the Atlantic coast. U.S. Geol. Surv. Circ. 1262, http://water.usgs.gov/pubs/circ/2003/circ1262/.

Boehm, A. B.; Shellenbarger, G. G.; and Paytan, A. 2004. Groundwater discharge: a potential association with fecal indicator bacteria in the surf zone. Environ. Sci. Technol. 38:3558-3566.
Bratton, J. F. 2007. The importance of shallow confining units to submarine groundwater flow. In Sanford, W.; Langevin, C.; Polemio, M.; and Povinec, P., eds. A new focus on groundwater-seawater interactions. IAHS Publ. 312:28-36.

Bratton, J. F.; Böhlke, J. K.; Krantz, D. E.; and Tobias, C. R. 2009. Flow and geochemistry of groundwater beneath a back-barrier lagoon: the subterranean estuary at Chincoteague Bay, Maryland, USA. Mar. Chem. 113:78-92. 
Bratton, J. F.; Böhlke, J. K.; Manheim, F. M.; and Krantz, D. E. 2004. Submarine ground water in Delmarva Peninsula coastal bays: ages and nutrients. Ground Water 42:1021-1034.

Burnett, W. 1999. Offshore springs and seeps are focus of working group. EOS: Trans. Am. Geophys. Union 80: $13-15$.

Burnett, W. C. ; Aggarwal, P. K. ; Aureli, A.; Bokuniewicz, H.; Cable, J. E.; Charette, M. A.; Kontar, E., et al. 2006. Quantifying submarine groundwater discharge in the coastal zone via multiple methods. Sci. Total Environ. 367:498-543.

Burnett, W. C.; Bokuniewicz, H.; Huettel, M.; Moore, W. S.; and Taniguchi, M. 2003. Groundwater and pore water inputs to the coastal zone. Biogeochemistry 66: 3-33.

Burnett, W. C.; Kim, G.; and Lane-Smith, D. 2001. A continuous radon monitor for assessment of radon in coastal ocean waters. J. Radioanal. Nucl. Chem. 249: 167-172.

Burnett, W. C.; Santos, I. R.; Weinstein, Y.; Swarzenski, P. W.; and Herut, B. 2007. Remaining uncertainties in the use of Rn-222 as a quantitative tracer of submarine groundwater discharge. In Sanford, W.; Langevin, C.; Polemio, M.; and Povinec, P., eds. A new focus on groundwater-seawater interactions. IAHS Publ. 312: 109-118.

Cable, J. E.; Burnett, W. C.; Chanton, J. P.; and Weatherly, L. G. 1996. Estimating groundwater discharge into the northeastern Gulf of Mexico using radon-222. Earth Planet. Sci. Lett. 144:591-604.

Chadwick, R. A.; Zweigel, P.; Gregersen, U.; Kirby, G. A.; Holloway, S.; and Johannessen, P. N. 2004. Geological reservoir characterization of a $\mathrm{CO}_{2}$ storage site: the Utsira Sand, Sleipner, northern North Sea. Energy 29:1371-1381.

Charette, M. A. 2007. Hydrologic forcing of submarine groundwater discharge: insight from a seasonal study of radium isotopes in a groundwater-dominated salt marsh estuary. Limnol. Oceanogr. 52:230-239.

Charette, M. A.; Sholkovitz, E. R.; and Hansel, C. 2005. Trace element cycling in a subterranean estuary. I. Geochemistry of the permeable sediments. Geochim. Cosmochim. Acta 69:2095-2109.

Colbourne, E. B., and Hay, A. E. 1990. An acoustic remote sensing and submersible study of an Arctic submarine spring plume. J. Geophys. Res. 95:13,219-13,234.

Crusius, J.; Koopmans, D.; Bratton, J.; Charette, M.; Kroeger, K.; Henderson, P.; Ryckman, L.; Halloran, K.; and Colman, J. 2005. Submarine groundwater discharge to a small estuary estimated from radon and salinity measurements and a box model. Biogeosciences 2: 141-157.

Culter, J. K. 2006. Exploration of the West Florida Shelf blue holes: investigation of physical and biological characteristics and archaeological implications of unique karst features. American Geophysical Union, Fall Meeting 2006, abstract OS34A-08.

Dale, R. K., and Miller, D. C. 2008. Hydrologic interac- tions of infaunal polychaetes and intertidal groundwater discharge. Mar. Ecol. Progr. Ser. 363:205-215.

Dugan, B., and Flemings, P. B. 2000. Overpressure and fluid flow in the New Jersey Continental Slope: implications for slope failure and cold seeps. Science 289: 288-291.

- 2002. Fluid flow and stability of the U.S. continental slope offshore New Jersey from the Pleistocene to the present. Geofluids 2:137-146.

Edmunds, W. M. 2001. Palaeowaters in European coastal aquifers: the goals and main conclusions of the PALAEAUX Project. In Edmunds, W. M., and Milne, C. J., eds. Palaeowaters in coastal Europe: evolution of groundwater since the Late Pleistocene. Geol. Soc. Spec. Publ. 189:1-16.

Flemings, P. B.; Long, H.; Dugan, B.; Germaine, J.; John, C.; Behrmann, J. H.; Sawyer, D.; and IODP Expedition 308 Scientists. 2008. Pore fluid overpressure measured with penetrometers on the continental slope, Gulf of Mexico. Earth Planet. Sci. Lett. 269:309-324.

Fleury, P.; Bakalowicz, M.; and de Marsily, G. 2007. Submarine springs and coastal karst aquifers: a review. J. Hydrol. 339:79-92.

Foyle, A. M.; Henry, V. J.; and Alexander, C. R. 2002. Mapping the threat of seawater intrusion in a regional coastal aquifer-aquitard system in the southeastern United States. Environ. Geol. 43:151-159.

Gagan, M. K.; Ayliffe, L. K.; Opdyke, B. N.; Hopley, D.; Scott-Gagan, H.; and Cowley, J. 2002. Coral oxygen isotope evidence for recent groundwater fluxes to the Australian Great Barrier Reef. Geophys. Res. Lett. 29: 1982, doi:10.1029/2002GL015336.

Giblin, A. E., and Gaines, A. G. 1990. Nitrogen dynamics in a marine embayment: the importance of groundwater. Biogeochemistry 10:309-328.

Green, A. N.; Goff, J. A.; and Uken, R. 2007. Geomorphological evidence for upslope canyon-forming processes on the northern KwaZulu-Natal shelf, SW Indian Ocean, South Africa. Geo-Mar. Lett. 27:399-409.

Harrar, W. G.; Williams, A. T.; Barker, J. A.; and van Camp, M. 2001. Modelling scenarios for the emplacement of palaeowaters in aquifer systems. In Edmunds, W. M., and Milne, C. J., eds. Palaeowaters in coastal Europe: evolution of groundwater since the Late Pleistocene. Geol. Soc. Spec. Publ. 189:213-229.

Hathaway, J. C.; Poag, C. W.; Valentine, P. C.; Miller, R. E.; Schultz, D. M.; Manheim, F. T.; Kohout, F. A.; Bothner, M. H.; and Sangrey, D. A. 1979. U.S. Geological Survey core drilling on the Atlantic shelf. Science 206: 515-527.

Hughes, J. D.; Vacher, H. L.; and Sanford, W. E. 2007. Three-dimensional flow in the Florida platform: theoretical analysis of Kohout convection at its type locality. Geology 35:663-666.

- 2009. Temporal response of hydraulic head, temperature, and chloride concentrations to sea-level changes, Floridan aquifer system, USA. Hydrogeol. J. doi:10.1007/s10040-008-0412-0.

Hunt, C. D., Jr. 2007. Ground-water nutrient flux to coastal waters and numerical simulation of waste- 
water injection at Kihei, Maui, Hawaii. U.S. Geol. Surv. Sci. Investig. Rep. 2006-5283, 69 p.

Johannes, R. E. 1980. The ecological significance of the submarine discharge of groundwater. Mar. Ecol. Progr. Ser. 3:365-373.

Johnson, D. W. 1939. The origin of submarine canyons: a critical review of hypotheses. New York, Columbia University Press, 126 p.

Kazemi, G. A. 2008. Editor's message: submarine groundwater discharge studies and the absence of hydrogeologists. Hydrogeol. J. 16:201-204.

Kohout, F. A. 1966. Submarine springs: a neglected phenomenon of coastal hydrology. Hydrology 26:391-413. . 1967. Ground-water flow and the geothermal regime of the Floridian Plateau. Trans. Gulf Coast Assoc. Geol. Soc. 17:339-354.

Kohout, F. A.; Meisler, H.; Meyer, F. W.; Johnston, R. H.; Leve, G. W.; and Wait, R. L. 1988. Hydrogeology of the Atlantic continental margin. In Sheridan, R. E., and Grow, J. A., eds. Geology of North America, vol. I-2. Boulder, CO, Geological Society of America, p. 463-480.

Krest, J. M.; Moore W. S.; Gardner, L. R.; and Morris, J. 2000. Marsh nutrient export supplied by groundwater discharge: evidence from Ra measurements. Glob. Biogeochem. Cycles 14:167-176.

Kroeger, K. D., and Charette, M. A. 2008. Nitrogen biogeochemistry of submarine groundwater discharge. Limnol. Oceanogr. 53:1025-1039.

Levin, L. 2005. Ecology of cold seep sediments: interactions of fauna with flow, chemistry and microbes. Oceanogr. Mar. Biol. Annu. Rev. 43:1-46.

Li, H.; Boufadel, M. C.; and Weaver, J. W. 2008. Tideinduced seawater-groundwater circulation in shallow beach aquifers. J. Hydrol. 352:211-224.

Li, H.; Li, G.; Cheng, J.; and Boufadel, M. C. 2007. Tideinduced head fluctuations in a confined aquifer with sediment covering its outlet at the sea floor. Water Resour. Res. 43:W03404, doi:10.1029/2005WR004724.

Maliva, R. G.; Guo, W.; and Missimer, T. M. 2007. Vertical migration of municipal wastewater in deep injection well systems, South Florida, USA. Hydrogeol. J. 15:1387-1396.

Manheim, F. T.; Krantz, D. E.; and Bratton, J. F. 2004. Studying ground water beneath Delmarva coastal bays using electrical resistivity. Ground Water 42:10521068.

McAuley, S. D.; Barringer, J. L.; Paulachok, G. N.; Clark, J. S.; and Zapecza, O. S. 2001. Ground-water flow and quality in the Atlantic City 800 -foot sand, New Jersey. N. J. Geol. Surv. Rep. GSR 41, 86 p.

McCoy, C. A., and Corbett, D. R. 2009. Review of submarine groundwater discharge (SGD) in coastal zones of the Southeast and Gulf Coast regions of the United States with management implications. J. Environ. Manag. 90:644-651.

McGowan, K. T., and Martin, J. B. 2007. Chemical composition of mangrove-generated brines in Bishop Harbor, Florida: interactions with submarine groundwater discharge. Mar. Chem. 104:58-68.
Meisler, H.; Leahy, P. P.; and Knobel, L. L. 1984. Effect of eustatic sea-level changes on saltwater-freshwater relations in the North Atlantic Coastal Plain. U.S. Geol. Surv. Water Suppl. Pap. 2255, 28 p.

Michael, H. A.; Mulligan, A. E.; and Harvey, C. F. 2005. Seasonal oscillations in water exchange between aquifers and the coastal ocean. Nature 436:1145-1148.

Moore, W. S. 1996. Large groundwater inputs to coastal waters revealed by ${ }^{226} \mathrm{Ra}$ enrichments. Nature 380 : 612-614.

. 1999. The subterranean estuary: a reaction zone of ground water and sea water. Mar. Chem. 65:111125.

- 2010. The effect of submarine groundwater discharge on the ocean. Annu. Rev. Mar. Sci. 2:59-88.

Moore, W. S.; Sarmiento, J. L.; and Key, R. M. 2008. Submarine groundwater discharge revealed by ${ }^{228} \mathrm{Ra}$ distribution in the upper Atlantic Ocean. Nature Geosci. 1:309-311.

Mulligan, A. E., and Charette, M. A. 2006. Intercomparison of submarine groundwater discharge estimates from a sandy unconfined aquifer. J. Hydrol. 327:411425.

Orange, D. L.; Anderson, R. S.; and Breen, N. 1994. Regular submarine canyon spacing in the submarine environment: the link between hydrology and geomorphology. GSA Today 4:36-39.

Paul, J. H.; Rose, J. B.; Jiang, S. C.; Zhou, X.; Cochran, P.; Kellogg, C.; Kang, J. B.; Griffin, D.; Farrah, S.; and Lukasik, J. 1997. Evidence for groundwater and surface marine water contamination by waste disposal wells in the Florida Keys. Water Res. 31:1448-1454.

Paull, C. K.; Chanton, J. P.; Martens, C. S.; Fullagar, P. D.; Neumann, C.; and Coston, J. A. 1991. Seawater circulation through the flank of the Florida platform: evidence and implications. Mar. Geol. 102:265-279.

Paull, C. K.; Hecker, B.; Commeau, R.; Freeman-Lynde, R. P.; Neumann, C.; Corso, W. P.; Golubic, S.; Hook, J. E.; Sikes, E.; and Curray, J. 1984. Biological communities at the Florida escarpment resemble hydrothermal vent taxa. Science 266:965-967.

Paytan, A.; Shellenbarger, G. G.; Street, J. H.; Gonneea, M. E.; Davis, K.; Young, M. B.; and Moore, W. S. 2006. Submarine groundwater discharge: an important source of new inorganic nitrogen to coral reef ecosystems. Limnol. Oceanogr. 51:343-348.

Person, M.; Dugan, B.; Swenson, J. B.; Urbano, L.; Stott, C.; Taylor, J.; and Willett, M. 2003. Pleistocene hydrogeology of the Atlantic continental shelf, New England. GSA Bull. 115:1324-1343.

Portnoy, J. W.; Nowicki, B. L.; Roman, C. T.; and Urish, D. W. 1998. The discharge of nitrate-contaminated groundwater from developed shoreline to marshfringed estuary. Water Resour. Res. 34:3095-3104.

Rachold, V.; Bolshiyanov, D. Y.; Grigoriev, M. N.; Hubberten, H.-W.; Junker, R.; Kunitsky, V. V.; Merker, F.; Overduin, P. P.; and Schneider, W. 2007. Nearshore arctic subsea permafrost in transition. EOS: Trans. Am. Geophys. Union 88:149-150. 
Robb, J. M. 1984. Spring sapping on the lower continental slope, offshore New Jersey. Geology 12:278-282.

Robinson, C.; Gibbes, B.; and Li, L. 2006. Driving mechanisms for groundwater flow and salt transport in a subterranean estuary. Geophys. Res. Lett. 33:L03402, doi:10.1029/2005GL025247.

Robinson, C.; Li, L.; and Prommer, H. 2007. Tide-induced recirculation across the aquifer-ocean interface. Water Resour. Res. 43:W07428, doi:10.1029/2006WR005679.

Shaw, T. J.; Moore, W. A.; Kloepper, J.; and Sochaski, M. A. 1998. The flux of barium to coastal waters of the southeastern USA: the importance of submarine groundwater discharge. Geochim. Cosmochim. Acta 62:3047-3054.

Smith, C. G.; Cable, J. E.; and Martin, J. B. 2008. Episodic high intensity mixing events in a subterranean estuary: effects of tropical cyclones. Limnol. Oceanogr. 53: 666-674.

Stieglitz, T. C. 2005. Submarine groundwater discharge into the near-shore zone of the Great Barrier Reef, Australia. Mar. Pollut. Bull. 51:51-59.

Street, J. H.; Knee, K. L.; Grossman, E. E.; and Paytan, A. 2008. Submarine groundwater discharge and nutrient addition to the coastal zone and coral reefs of leeward Hawai'i. Mar. Chem. 109:355-376.

Swarzenski, P. W.; Reich, C. D.; Spechler, R. M.; Kindinger, J. L.; and Moore, W. S. 2001. Using multiple geochemical tracers to characterize the hydrogeology of the submarine spring off Crescent Beach, Florida. Chem. Geol. 179:187-202.

Taniguchi, M.; Burnett, W. C.; Cable, J. E.; and Turner,
J. V. 2002. Investigations of submarine groundwater discharge. Hydrol. Process. 16:2115-2129.

Taniguchi, M.; Nakano, T.; Onodera, S.; Ishitobi, T.; Hosono, T.; Umezawa, Y.; and Fujii, T. 2008. Effects of submarine groundwater discharge on seashell ecosystem in the coastal zone. Meeting abstracts of the 2008 Ocean Sciences Meeting, Orlando, FL, p. 403.

Vacher, H. L. 1988. Dupuit-Ghyben-Herzberg analysis of strip island lenses. GSA Bull. 100:580-591.

Valentine, P. C.; Uzmann, J. R.; and Cooper, R. A. 1980. Geology and biology of Oceanographer submarine canyon. Mar. Geol. 38:283-312.

Valiela, I.; Costa, J.; Foreman, K. H.; Teal, J. M.; Howes, B.; and Aubrey, D. 1990. Transport of groundwaterborne nutrients from watersheds and their effects on coastal waters. Biogeochemistry 10:177-197.

Valiela, I.; Teal, J. M.; Volkmann, S.; Shafer, D.; and Carpenter, E. J. 1978. Nutrient and particulate fluxes in a salt marsh ecosystem: tidal exchanges and inputs by precipitation and groundwater. Limnol. Oceanogr. 23: 798-812.

Wilson, A., and Ruppel, C. 2007. Salt tectonics and shallow subseafloor fluid convection: models of coupled fluid-heat-salt transport. Geofluids 7:377-386, doi: 10.1111/j.1468-8123.2007.00191.x.

Wilson, A. M. 2003. The occurrence and chemical implications of geothermal convection in continental shelves. Geophys. Res. Lett. 30:2127, doi:10.1029/ 2003GL018499.

. 2005. Fresh and saline groundwater discharge to the ocean: a regional perspective. Water Resour. Res. 41:W02016, doi:10.1029/2004WR003399. 